\title{
Artigos
}

\section{Noite de terror na cidade luz: os atos terroristas em Paris e a avaliação da imagem de destino por turistas brasileiros}

\author{
Night of terror in the city of light: the terrorist acts in Paris and the \\ evaluation of the destination image by Brazilian tourists
}

\section{La noche de terror en la ciudad luz: Ios actos terroristas en París y la evaluación de la imagen de destino por turistas brasileños}

\section{Marcela Lidianny do Amaral Ferreira1; Pollyanna Fraga Graciano1; Sérgio Rodrigues Leal1; Marconi Freitas da Costa ${ }^{1}$}

1 Universidade Federal de Pernambuco (UFPE), Recife, PE, Brasil.

\begin{tabular}{|c|c|}
\hline & Resumo \\
\hline Palavras-chave: & $\begin{array}{l}\text { O terrorismo contemporâneo pode ser considerado um dos males do século XXI e suas ações } \\
\text { têm atingido um número cada vez maior de alvos não combatentes. Os grupos extremistas }\end{array}$ \\
\hline & realizar os seus ataques. Os atentados almejam alcançar um maior número de kafirs, termo \\
\hline Imagem do Destino. & para definir os incrédulos ou infiéis da doutrina islâmica, ou obter uma maior atenção da \\
\hline Paris. & mídia. Assim, o presente estudo objetivou entender como turistas brasileiros, que estavam \\
\hline Turistas Brasileiros. & $\begin{array}{l}2015 \text { na imagem turística da cidade. A investigação foi qualitativa exploratória com a trian- } \\
\text { gulação dos dados: pesquisa documental, questionários abertos e depoimentos em vídeos, } \\
\text { com o uso da análise de conteúdo. Os resultados mostram um impacto mediano na ativi- } \\
\text { dade turística, porém pouco importante na imagem da cidade de Paris nos meses subse- } \\
\text { quentes aos atentados, sendo o fluxo de visitantes reestabelecido em curto prazo. A rele- } \\
\text { vância primordial deste artigo foi compreender o impacto na demanda turística pós-atenta- } \\
\text { dos terroristas a partir da percepção dos turistas sob a imagem do destino. }\end{array}$ \\
\hline
\end{tabular}

Abstract

Keywords:

Terrorism.

Image of Destiny.

Paris.

Brazilian Tourists.
Contemporary terrorism may be considered one of the ills of the 21st century and its actions have reached an increasing number of non-combatant targets. The extremist groups are looking for places with large circulation of people as sights to carry out their attacks. The attacks aim to reach a greater number of kafirs, term to define the unbelievers or infidels of the Islamic doctrine, or to obtain a greater attention of the media. Thus, the present study aimed to understand how Brazilian tourists, who were in Paris, perceive the interference of the night of the attacks in November 2015 in the tourist image of the city. The research was qualitative with the triangulation of data: documentary research, open questionnaires and testimonials in videos, with the use of content analysis. The results show a medium impact on tourism activity, but little importance in the image of the city of Paris in the months following the attacks, with the flow of visitors reestablished in the short term. The primary relevance of this article was to understand the impact on tourist demand after terrorist attacks from the perception of tourists under the image of the destination. 
Resumen

Palavras clave:

Terrorismo.

Imagen del Destino.

París.

Turistas Brasileños.

Revisado por pares.

Recebido em: 22/04/2018.

Aprovado em: 18/07/2018.

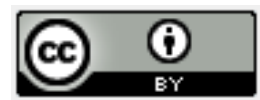

El terrorismo contemporáneo puede ser considerado uno de los males del siglo XXI y sus acciones han alcanzado un número cada vez mayor de blancos no combatientes. Los grupos extremistas están buscando lugares con gran circulación de personas como puntos turísticos para realizar sus ataques. Los atentados anhelan alcanzar un mayor número de kafirs, término para definir a los incrédulos o infieles de la doctrina islámica, o obtener una mayor atención de los medios. Así, el presente estudio tuvo como objetivo entender cómo los turistas brasileños, que se encontraban en París, perciben la interferencia de la noche de los atentados en noviembre de 2015 en la imagen turística de la ciudad. La investigación fue cualitativa con la triangulación de los datos: investigación documental, cuestionarios abiertos y testimonios en videos, con el uso del análisis de contenido. Los resultados muestran un impacto mediano en la actividad turística, pero poco importante en la imagen de la ciudad de París en los meses posteriores a los atentados, siendo el flujo de visitantes restablecido a corto plazo. La relevancia primordial de este artículo fue comprender el impacto en la demanda turística post-atentados terroristas a partir de la percepción de los turistas bajo la imagen del destino.

Como citar: Ferreira, M. L. A.; Graciano, P. F.; Leal, S. R.; Costa, M. F. (2019). Noite de terror na cidade luz: os atos terroristas em Paris e a avaliação da imagem de destino por turistas brasileiros. Revista Brasileira de Pesquisa em Turismo, São Paulo, 13 (1), p. 19-39, jan./abr. http://dx.doi.org/10.7784/rbtur.v13i1.1445

\section{INTRODUÇÃO}

O terrorismo é considerado desde o século XX, e mais precisamente no século XXI, o principal problema que o mundo contemporâneo está lidando (Goldman \& Neubauer-Shani, 2017). Por diversas vezes os agentes terroristas conseguiram propagar ao mundo seus ideais, principalmente religiosos, através da disseminação do medo, terror e provocando muitas mortes e perdas (Nye Jr., 2005; Frey, Luechinger \& Stutzer, 2007). Alguns autores (Bergen, 2001; Wright, 2007; Burke, 2007) pesquisaram sobre o surgimento do radicalismo islâmico, mostrando o desenvolvimento das teorias ortodoxas islâmicas no oriente médio e como isto afetaria o mundo posteriormente, com ataques terroristas de grandes proporções.

O chamado novo terrorismo, deu-se após os anos 1990, quando os grupos terroristas já não estavam mais atuando apenas isolados em seus territórios, mas agindo em múltiplas nações, assim, conseguiram expandir suas ideias através de interpretações extremistas da religião islâmica (Petkova, Martinez, Schlegelmilch \& Redlener, 2017). Também, neste novo contexto, é possível se vê as maiores perdas patrimoniais e vitais causadas pelas as ações terroristas (Hoffman, 1998; Bergesen \& Han, 2005).

Em Paris, entre os dias 13 e 14 de novembro de 2015, ocorreram oito sucessivos ataques, matando centenas de pessoas e deixando mais de 350 feridas (Estrada \& Koutronas, 2016). Segundo Nevalsky (2015), o acontecido, intitulado pelos canais de comunicação como "noite de terror", foi relacionado ao Estado Islâmico - El (antigo ISIS - Islamic State of Iraq and Syria). 0 grupo extremista muçulmano planejou o feito, vingando os bombardeios e as intervenções militares franceses na Síria e no Iraque, como também o apoio político aos Estados Unidos e as afrontas realizadas contra o profeta Maomé, pela revista satírica Charlie Hebdo (Woo, 2015).

A França possui aproximadamente $10 \%$ de sua população formada por muçulmanos, o que a torna um dos países da Europa com maior população árabe e Islâmica. Esta elevada presença árabe-Islâmica tem forte relação com o período colonianista francês (no Norte da África, no Oriente Médio e no Sudeste Asiático), principalmente com os territórios dominados na África que eram habitados por povos árabes, com fundamentos do Islamismo (Hourani, 2013). Atualmente, existem alguns conflitos dos franceses com os imigrantes, sob o pretexto de que estes estão querendo islamizar a França.

O país vem sofrendo sucessivos ataques do radicalismo islâmico, sobretudo a partir de 2015, ano em que foram mortas 149 pessoas e outras centenas ficaram feridas, além das tentativas de ações frustradas pelo serviço de inteligência do país (Estrada \& Koutronas, 2016). Estes atentados são justificados pela discriminação e exclusão social ao grande número de moradores de comunidade muçulmana no país (Bozzoli \& Muller, 2011). A lei da laicidade de 1905, aprovada em 2004, trouxe grande insatisfação para uma parte dos muçulmanos por causa da proibição do uso de símbolos religiosos e orações em instituições de ensino 
e, no ano de 2010, da proibição do uso do niqab (véu islâmico que cobre o rosto e mostra apenas os olhos), fortalecendo assim a insatisfação dos grupos extremistas (Castanho-Silva, 2018). Há algumas décadas que a França é atingida pelo terrorismo islâmico, sobretudo em pontos estratégicos, tais como, companhias aéreas e hotéis, que impactam negativamente o turismo da cidade.

A indústria do turismo e os ataques terroristas estão distantes em suas proposições conceituais, mas se utilizam de critérios em comum para realização de suas ações, como o estreitamento de fronteiras, envolvimento de pessoas de diversas localidades do mundo e uso da tecnologia tanto para deslocamentos como para a comunicação (Sonmez \& Apostolopoulos, 1999; Samitas, Asteriou, Polyzos \& Kenourgios, 2018). Com os atentados em terras francesas a partir de 2015, foi estimado pelo Comitê da llê de France e Comitê Regional de Turismo (CRT) da França, em seu relatório divulgado em 2016, que houve sérios impactos negativos para a atividade turística, como, por exemplo, queda no número de pernoites nos meios de hospedagens. A redução do número da demanda representa uma queda de $4,7 \%$ no turismo da cidade, isto reflete uma baixa de 1,3 bilhões de euros em arrecadação no setor turístico em 2016 (Seraphin, 2017).

No Turismo, a tomada de decisão na escolha de qualquer destino abrange diversos aspectos internos e externos, alguns deles são a percepção de risco e, sobretudo, a segurança na utilização dos serviços (Sonmez \& Apostolopoulos, 1999; Liu \& Pratt, 2017). Há alguns modelos que tentam explicar a tomada de decisão em turismo, um deles é o de escolha de destinos de Crompton (1992), que explica a tomada de decisão por parte do turista de forma racional e ativa, onde o cliente possui alto grau de envolvimento na escolha do destino a ser visitado, levando em consideração forças internas motivadas por um conhecimento prévio ou de experiências passadas e forças externas explicadas por informações provenientes de terceiros e até da mídia (Lepp \& Gisbon 2008). No modelo, há os conjuntos de destinos que não serão escolhidos, conjunto inepto e conjunto rejeitado, os critérios de descarte destes se dão pelas experiências prévias desagradáveis e comentários negativos (Marion, Reintinger \& Schmude, 2015).

Estes fatos internos e externos junto à percepção de risco que surge após um incidente terrorista podem determinar a motivação de um turista de não visitar a localidade (Buigut \& Amendah, 2016). Isto quer dizer que o novo terrorismo transnacional ao se apropriar da mídia internacional para promover seus valores e demonstrar sua força, impacta negativamente o turismo (Walters, Wallin \& Hartley, 2018). Logo, a imagem do destino configura um papel de grande importância, pois esta representa um conjunto de crenças, ideias, impressões globais e sentimentos necessários à tomada de decisão de um turista para selecionar um local para visitar (Embacher \& Buttler, 1989; Prayag, 2008; Molina, Gómez \& Consuegra, 2010). Assim, o sentimento de insegurança, a xenofobia e as políticas públicas de restrições nas fronteiras podem ser causas ou contribuir para a diminuição no fluxo turístico.

A partir dos fatos e das teorias interconectadas, o presente estudo objetivou entender como turistas brasileiros, que estavam em Paris, percebem a interferência da noite dos atentados em 2015 na imagem turística da cidade. Para tanto, foi realizada uma investigação qualitativa exploratória, triangulando a pesquisa documental, com questionários abertos e depoimentos em vídeos. As três fases da análise de conteúdo de Bardin (2011), pré-análise, exploração do material e tratamento dos resultados, auxiliaram no processo de exteriorização dos fatos. A pesquisa se justifica pela necessidade de aprofundar a teoria sobre a imagem de destino (Liu, Li \& Yang, 2015) e também sobre o terrorismo (Buigut \& Amendah, 2018; Silke, 2003), e ainda como a cultura do medo, disseminada pelos atos terroristas, impacta no fenômeno do turismo. A principal contribuição desta pesquisa é identificar como os indivíduos percebem a imagem de uma destinação turística após um atentado terrorista.

O artigo está estruturado com esta seção introdutória. A partir da próxima seção, o artigo apresenta uma breve revisão da literatura sobre o terrorismo, turismo e terrorismo internacional e imagem do destino turístico. A terceira seção aborda os procedimentos metodológicos. Em seguida, é apresentada a análise dos dados e discussão dos resultados. Por fim, é tratado o tópico da conclusão da pesquisa. 


\section{REVISÃO DA LITERATURA}

\subsection{Terrorismo}

Etimologicamente, de acordo com o site Origem da Palavra (2017), terrorismo surge do termo terror, derivando do latim terror significando "medo" e terrere que tem significação "assustar" ou "causar medo". 0 vocábulo terrorismo tem a mesma origem da palavra terrível.

Como não há um conceito definitivo do que é terrorismo, cada pesquisador ou interessado na área irá definir dependendo do ponto de vista do ator da observação (Samitas et al., 2018). Também há problemas, segundo Cronin (2002), na conceituação pela difícil categorização dos eventos, já que a classificação de cada atentado está sujeita à sua legitimidade política. Cronin (2002) ainda defende que o terrorismo é uma ação brusca ou ameaça desta ação, que age violentamente contra vítimas inocentes, a fim de obter vitórias políticas. 0 terrorismo ainda pode ser caracterizado como uma prática realizada por um grupo ou Estado contra outro grupo ou Estado através do uso da brutalidade (assassinatos, sequestros e crimes), com a finalidade de construir um ambiente de instabilidade emocional pública para alcançar fins políticos, sociais ou religiosos (Shaw, 2000; Choi, 2010).

O problema encontrado para definir os ataques terroristas, dá-se principalmente pelo fato da não unidade sobre o que seria uma ação terrorista (Sandler, 2015). Deste modo, de acordo com Drakos e Kutan (2003), também não há como categorizar de forma ética quando um ataque é maior ou mais perigoso que outro, sendo levado em consideração o local do ocorrido e quem é atingido. Isto quer dizer que, mesmo que um país subdesenvolvido tenha sofrido um ataque com maior número de vítimas fatais, aparecerá menos na mídia e consequentemente menos nas estatísticas, em relação a um ataque em país desenvolvido (Nitsch \& Schumacher, 2004; Kiliçlar, Usakli \& Tayfun, 2017).

No momento atual, o número de vítimas com os atentados vêm aumentando (Samitas et al., 2018), ao passo que os ataques estão ganhando maiores proporções, mesmo que em menor número de ocorrência. 0 número de ataques letais, segundo Frey, Luechinger \& Stutzer (2007), decorre da especialização dos grupos fundamentalistas no que diz respeito às tecnologias usadas e por preferirem vítimas em massa, a fim de que suas causas atinjam maiores proporções midiáticas.

O fundamentalismo islâmico, sua jihad e o terrorismo começam a ganhar maiores proporções no período do pós-guerra a partir da década de 1950, principalmente, quando o colonialismo britânico na Ásia entra em choque com as pretensões russas de adentrar no mercado asiático por meio do Afeganistão, culminando com a invasão soviética do país (Wrigth, 2007). Devido à Guerra Fria, na tentativa de conter o avanço do comunismo, os EUA passam a financiar os mujahidin (guerreiros santos) para combater os russos no território afegão. Porém, esses guerreiros posteriormente uniram-se à causa islâmica e treinaram outros combatentes (Bergen, 2001).

Assim, o imperialismo norte-americano, que o tornou expoente máximo de uma cultura ocidental a ser dizimada pela jihad islâmico, proporcionou não apenas treinamento tático, mas também ideológico das principais lideranças e mentores intelectuais da Al-Qaeda. Esses fatores juntamente com a inoperância de organizações como a ClA e o FBI, mesmo diante de informações prenunciando as ações de Bin Laden que resultaram nos atentados de 11/09, que mudaram o rumo da história do terrorismo internacional (Bergen, 2001; Burke, 2007; Wrigth, 2007).

Diante disto, os fenômenos terroristas cruzam fronteiras e atingem pessoas das mais variadas nações e seus praticantes fazem uso da tecnologia durante as ações e usam ferramentas da comunicação internacional, como já relatado na parte introdutória deste trabalho (Sonmez \& Apostolopoulos, 1999). Estas práticas impactam o desenvolvimento dos serviços da indústria do turismo, por isto a existência de algumas análises para alcançar entendimento na relação do terrorismo e do turismo (Araña \& León, 2008; Buigut \& Amendah, 2016). 


\subsection{Turismo e Terrorismo Internacional}

O setor turístico, como todos os setores de serviços, pode sofrer com a vulnerabilidade por diversas causas (Liu \& Pratt, 2017). Causas naturais como furacões, terremotos e atividades vulcânicas ou efeitos antrópicos como a destruição de patrimônios, a construção de represas destruindo ambientes naturais e as guerras. Qualquer que seja a motivação, a consequência será única: o impacto negativo que o setor sofrerá, seja sobre a oferta ou a demanda turística (Samitas et al., 2018). Quando as causas são no ambiente natural a resposta de retorno da normalidade é mais rápida ou com menos esforço para alcançar a demanda (Sonmez \& Apostolopoulos, 1999). De outro modo, quando a causa da anormalidade é uma ação do homem, como o terrorismo, o retorno deste consumidor requer mais esforço e mesmo assim com o risco de não haver recuperação, maculando a imagem do destino onde ocorreu o ataque (Tarlow, 2006).

Várias crises podem afetar os negócios, a atividade turística e a tomada de decisão do viajante sobre qual destino escolher (Walters, Wallin \& Hartley, 2018). Segundo Stafford, Yu e Armoo (2002) há fatores externos e internos que justificam a afirmação anterior. Os fatores internos estão associados às falhas de gerenciamento das empresas, como má conduta, fraudes e falta de valores. Já os fatores externos, conforme Freytag, Krüger, Meierrieks \& Schneider (2011), são divididos em dois ambientes: os físicos e o ambiente social ou humano.

Os ambientes físicos podem ser caracterizados pelos desastres naturais e pelas falhas tecnológicas. 0 ambiente social ou humano está subdividido em dois tipos, o primeiro seria os confrontos (podendo ser exemplificado pelas crises internas como os protestos sobre a insatisfação dos governos que vem surgindo no Brasil ao longo dos últimos anos) e o segundo tipo seria chamado de malevolência, onde seria exemplificado pelos ataques terroristas em regiões turísticas. Os serviços de turismo são afetados negativamente por estas situações (Amorim, Soares \& Tarlow, 2015), seja por conta de questões como terrorismo, instabilidade social ou criminalidade, mas tanto a oferta quanto a demanda se adaptam às situações, porém com grandes efeitos (Walters, Wallin \& Hartley, 2018).

Ainda que o motivo dos ataques de 11 de setembro de 2001 nos Estados Unidos não tenha sido contra o turismo, este atentado apresentou grande impacto na atividade e estimulou estratégias antes não aplicadas no controle de segurança internacional das viagens, principalmente nos aeroportos. Estima-se pelo Conselho Mundial de Viagens e Turismo (WTTC) que, após o acontecimento, houve uma queda de 10\% na demanda turística em todo o globo e aumento do desemprego no setor (Parra, 2015; Samitas et al., 2018). A partir da data houve um aumento de estudos relacionados aos impactos que um evento desta magnitude teria no turismo. Lepp e Gibson (2008) sugerem que o uso da mídia na exploração das notícias sobre os ataques, principalmente quando a ação for contra o Estado, aumentaria o terror, agregando mais membros às causas terroristas.

Com o passar dos anos, e após sucessivos ataques, as medidas de proteção foram ficando mais duras e as instalações mais monitoradas (Piazza, 2013). Logo, houve aumento dos ataques aos alvos mais vulneráveis, no caso, transeuntes em ambientes públicos, onde o fluxo de turistas se enquadra. Além deste público vulnerável, os terroristas escolhem destinos turísticos a fim de estimular a perda da atratividade local e queda de receitas para os líderes (Pizam \& Fleischer, 2002; Tarlow, 2006).

Os ataques terroristas são imprevisíveis e diferentes entre si (Freytag et al., 2011). As consequências negativas para os destinos atingidos, vítimas e empresas turísticas são diversas, uma das primeiras é o imediato cancelamento dos voos, seguida da redução das atividades turísticas, queda da demanda turística ou deslocamento desta demanda para lugares mais seguros, redução dos preços cobrados pelas empresas, problemas de operacionalização (perda de bagagens, filas gigantescas e atrasos de voos) (Pizam \& Fleischer, 2002; Paraskevas, 2013). 0 aumento dos gastos com medidas de segurança e publicidade para melhoria da imagem do destino faz as empresas repassarem estes custos para o consumidor (Ritchie, 2004; Buigut, 2018). 


\subsection{Imagem do Destino Turístico}

A imagem do destino foi tema de muitos debates acadêmicos no decorrer dos últimos 30 anos, evidenciandose como um dos principais objetos estudados no fenômeno do turismo (Prayag, 2008). Na década de 70 , Crompton (1979) já definia imagem como a soma de crenças, ideias, impressões e percepções dos indivíduos sobre certos lugares, eventos e objetos. Posteriormente, alguns a compreenderam como ideias e percepções concebidas de forma coletiva ou individualmente para um dado lugar (Embacher \& Buttler, 1989; Stylidis \& Cherifi, 2018). Ou ainda segundo uma definição mais holística, como a reunião de impressões globais e sentimentos se reunindo na construção da mesma (Echtner \& Ritchie, 1991).

A imagem é importante, pois exerce uma forte interferência no momento da escolha dos destinos, além de afetar no propósito de visitar novamente ou de indicar determinada localidade (Chi \& Qu, 2008; Molina, Gómez \& Consuegra, 2010). Os estudos sobre a imagem do destino são multidisciplinares, apresentando vertentes na antropologia, na sociologia, na geografia e, principalmente, no marketing (Gallarza, Saura \& Garcia, 2002). Assim, a imagem é uma marca utilizada para distinguir dois ou mais lugares e a construção desta visão positiva ocorre por meio do branding (Blain, Levy \& Ritchie, 2005; Foroudi et al., 2018). Apesar de todos estes estudos, a estrutura conceitual da imagem e algumas teorias a ela relacionadas carecem de maior investigação (Liu, Li \& Yang, 2015).

A imagem é composta de atributos, que são as características presentes nos cenários dos lugares, sendo distribuídas em diferentes aspectos, dimensões e formas (Echtner \& Ritchie, 1991; Beerli \& Martin, 2004; Chi \& Qu, 2008). As atitudes dos turistas e os motivos comportamentais são frequentemente alterados pela imagem, interferindo diretamente na escolha por dado destino, e os atributos são fatores imprescindíveis nesta decisão (Chon, 1990). Por isso, a formação da imagem possui grande variação de uma pesquisa para outra, pois são definidos a partir dos mais variados parâmetros (Bastida \& Huan, 2014).

Echtner e Richie (1991) propõem um modelo tridimensional, dividido nos binômios: funcional-psicológico, abordando a tangibilidade e abstração; o comum-único, com a peculiaridade e a generalidade; e atributoholístico, tratando de características isoladas e de maior abrangência. Outro estudo da década de 90 , afirma que a reunião de fatores psicológicos, sociais e estímulos externos ao se relacionarem constituirão a imagem de dado local (Baloglu \& Mccleary, 1999).

Já nos anos 2000, os estudos demonstravam outros entendimentos, por exemplo, Gallarza, Saura e Garcia (2002) indicaram um processo estático e outro dinâmico, no primeiro destaque para a interação entre imagem do destino e o turista; no segundo, a estrutura interagia com a formação da imagem. Por conseguinte, outros apontam a existência dos fatores sociodemográficos (idade, renda, gênero, ocupação, etc.) e psicológicos (valores, personalidade, conhecimento prévio, etc.), que integram o fator pessoal (Beerli e Martin, 2004). Logo, fica explícita a evolução de modelos menos complexos para modelos multidimensionais para avaliar a imagem do destino (Moraga, Artigas \& Irigoyen, 2012).

A motivação está estreitamente ligada à imagem do destino, tendo o fator psicológico como destaque, pois ainda que a decisão seja inerente ao individuo, algo neste âmbito o fará buscar pela redução do estresse, uma mudança de rotina, ou meramente, o novo, como explica o modelo de Iso-Ahola (Simková \& Holzner, 2014). A viagem não é fruto de um motivo único, a escolha é permeada por uma complexidade de elementos. Por isso, foram formulados os mais variados modelos de seleção de destinos nos últimos anos. A imagem atua como um componente fundamental em alguns deles. 0 estudo de Crompton (1979) divide as opções entre destinos conhecidos e não conhecidos, vários aspectos da definição de imagem podem ser identificados como requisitos para a seleção de um destino conhecido. No modelo de seleção de Schmöll (1977), há quatro dimensões agindo para amparar a decisão do turista, e a imagem está presente na dimensão de "variáveis externas".

Destarte, é perceptível um construto teórico de imagem ainda não unificado. Uma vez que o destino é elemento imprescindível ao produto turístico, e ambos responsáveis pela formação da experiência (Pine \& Gilmore, 1998), a ampliação dos estudos sobre a imagem em seus variados contextos é indicada. Assim, haverá maior compreensão da dinâmica entre a imagem do destino e os ideais e crenças coletivas dos indivíduos, e ainda uma orientação aos gestores para a criação de imagens mais favoráveis ao fluxo turístico (Chen et al., 2015). 


\section{MÉTODO DA PESQUISA}

O presente estudo foi feito por meio de uma pesquisa qualitativa exploratória (Laville \& Dionne, 1999). Creswell (2016) defende a triangulação das fontes e dos dados na pesquisa qualitativa para assegurar sua confiabilidade e validade. Assim, considerando estes aspectos, esta pesquisa fez uso da triangulação dos dados, valendo-se da pesquisa documental, questionários abertos e depoimentos do ocorrido por vídeos provenientes de três telejornais brasileiros (Jornal Hoje, Jornal Nacional e Fantástico).

Inicialmente, foi realizada a pesquisa documental por meio de uma revisão sistemática da literatura (RSL), que apresentou duas fases: a primeira foi exploratória, realizada pelo Google Acadêmico para verificar diante de quais formatos o tema era abordado, e a segunda foi direcionada para os artigos disponíveis pelo portal Periódicos Capes e também pelo Science Direct. No protocolo de busca dos artigos foram utilizadas as palavras: terrorismo, turismo, imagem de destino, e França, nos idiomas: português e inglês. Em um segundo momento, foi aplicado um questionário aberto em ambiente virtual (e-mail e mídias sociais), hospedado no Google Forms no mês de novembro de 2017. Foram obtidos 14 questionários mediante os quais se desejou captar as impressões de turistas brasileiros espectadores dos acontecimentos terroristas daquela época.

A amostra foi não-probabilística por conveniência (Sampieri, Collado \& Lucio, 2006), a partir da identificação de pessoas conhecidas pelos autores da pesquisa, que residiam em Paris e tinham presenciado as ações de terror, e poderiam indicar turistas brasileiros que passaram pela mesma situação. Sendo assim, a amostra também foi composta pela técnica de amostragem de bola de neve (snowball), em que os indivíduos participantes vão indicando outras pessoas para compor a amostra. Em seguida, realizaram-se buscas por grupos fechados na plataforma social Facebook, cujos integrantes correspondessem ao perfil dos interessados no propósito deste estudo. Na plataforma há um número relativo de grupos, porém decidiu-se por apenas disponibilizar o questionário nos grupos indicados pelas pessoas selecionadas no primeiro momento.

O questionário aberto mostrou-se como um dos possíveis instrumentos para capturar as informações necessárias à obtenção dos dados. Desta forma, estando esta ferramenta adequada ao propósito, partiu-se para a elaboração do documento não apenas focada no bom senso e na boa redação, mas em alguns critérios como redação sem ambiguidades, precisão e exclusão de perguntas indutoras, presuntivas e hipotéticas (Denzin \& Lincoln, 2006). O questionário aberto no formato eletrônico se tornou a opção mais válida para este estudo, pois $100 \%$ da amostra residem fora do Estado de residência dos pesquisadores ou do País. Logo, nem todos os indivíduos envolvidos se mostraram disponíveis para realizar contato via vídeo chamada. Assim, foram formuladas 11 questões com objetivo de avaliar: (a) sentimentos ao presenciar os atentados; (b) a reação da população após os atentados; (c) o impacto dos atentados na relação entre estrangeiros e franceses; (d) medidas de segurança impostas pelo governo; e (e) o impacto na atividade turística. As perguntas podem ser conferidas no Quadro 1.

Quadro 1 - Perguntas do Questionário Aberto

\begin{tabular}{|c|l|}
\hline \multicolumn{2}{|c|}{ Perguntas do questionário aberto } \\
\hline 1) & Onde você estava na noite do atentado? \\
\hline 2) & Qual foi o seu sentimento ao saber do ocorrido? \\
\hline 3$)$ & $\begin{array}{l}\text { Após o atentado, o presidente francês adotou algumas medidas de segurança. } \\
\text { Você achou válidas as ações? Justifique }\end{array}$ \\
\hline 4) & No geral, como foi a reação dos franceses? \\
\hline 5$)$ & $\begin{array}{l}\text { Pensando sobre os efeitos das ações adotadas pelo governo, você acha que a } \\
\text { população passou a se sentir mais segura ao longo do tempo? Por que? }\end{array}$ \\
\hline 6$)$ & $\begin{array}{l}\text { Quais ações o governo da França vem tomando ou deveria tomar para evitar novos } \\
\text { ataques? }\end{array}$ \\
\hline 7) & $\begin{array}{l}\text { Estas ações podem interferir na vida de estrangeiros que residam na França ou } \\
\text { que pretendam visitar a cidade de Paris? }\end{array}$ \\
\hline 8) & $\begin{array}{l}\text { Após o ocorrido, você tem sentido tratamento diferenciado com os estrangeiros } \\
\text { ou determinados grupos étnicos? }\end{array}$ \\
\hline 9) & $\begin{array}{l}\text { Em sua opinião, as pessoas continuam a visitar Paris, ou o fluxo de visitantes foi } \\
\text { reduzido em algum período após o atentado? }\end{array}$ \\
\hline 10) & Atualmente, você se sente seguro(a) na cidade de Paris? \\
\hline 11) & $\begin{array}{l}\text { Gostaríamos que nessa parte você se sentisse livre em detalhar qualquer infor- } \\
\text { mação sobre o ocorrido que não foi perguntada. }\end{array}$ \\
\hline Fonte: Elaborado pelos autores.
\end{tabular}


Posteriormente, a fim de validar os dados primários, efetuou-se uma varredura no YouTube por materiais que continham depoimentos de brasileiros que estavam na França no momento dos ataques. Assim, buscouse por depoimentos sobre a experiência dos indivíduos que trouxessem informações para serem trianguladas com as respostas do questionário aberto aplicado.

Para localizar os vídeos com os depoimentos dos brasileiros no Youtube foi utilizado o seguinte protocolo de busca: "atentado terrorista em Paris", "atentado no Stade de France" e "atentado na boate Bataclan". Com estas frases apareceram vários vídeos, no entanto, os vídeos que traziam depoimentos de brasileiros sobre o atentado ficaram restritos a apenas três jornais, da emissora Rede Globo, o Jornal Hoje, Jornal Nacional e o Fantástico. Um total de 10 vídeos foi encontrado, todos postados entre os dias 13 a 15 de novembro de 2015 no canal do Youtube.

Como a amostra da pesquisa é com brasileiros, os vídeos que não eram com brasileiros não foram selecionados. A edição das reportagens nos vídeos não mostra as perguntas dos repórteres, desta forma não há como avaliar se houve direcionamento nos depoimentos. A limitação deu-se, principalmente, pelo fato do tempo decorrido entre os atentados e a produção deste trabalho, visto que já se fazia dois anos dos atentados e possivelmente muitos dos materiais não estão mais disponibilizados na internet.

A análise do conteúdo foi utilizada como ferramenta metodológica para auxiliar na análise dos dados, pois é frequentemente utilizada para obter uma compreensão aprofundada das mais diversas formas de comunicação (Bauer, 2002). As mensagens são analisadas considerando a influência dos contextos para lograr uma fundamentação teórica (Franco, 2007). Bardin (2011), em seu estudo, demonstra a forte subjetividade dos objetos analisados, que arrastam o pesquisador para terrenos extremamente fecundos, sendo esta a perspectiva mais aplicada da atualidade. Três fases estão previstas no processo: a pré-análise, exploração do material e tratamento dos resultados. Na primeira fase, foi realizada a leitura flutuante, a preparação do material e foram estabelecidos indicadores. Durante a segunda fase foram criadas as categorias (code families) de forma apriorística, ou seja, foram predeterminadas a partir do objetivo proposto no estudo. A última fase ficou destinada às inferências e às interpretações dos resultados, condensando e destacando as informações relevantes.

\subsection{Criação das Categorias}

Após a definição e preparação das unidades de análise - questionários abertos e transcrição dos depoimentos - foram utilizados os construtos do terrorismo e o impacto na imagem do destino turístico para delinear as categorias que serviram como ferramentas analíticas dos dados. A categorização é um processo de classificação dos componentes de um conjunto por diferenciação e agrupamento a partir de critérios pré-determinados (Bauer, 2002; Franco, 2007). 0 critério pode ser semântico, sintático, léxico ou expressivo (Bardin, 2011). No presente estudo utilizou-se o semântico por apostar na temática como fator de união ou separação dos enunciados. Então, estipularam-se de maneira apriorística as categorias usadas na análise dos resultados, como demonstrado na Tabela 1.

A partir da definição das categorias, a análise transcorreu em quatro etapas: (i) efetuou-se um inventário nas transcrições para identificar as palavras de mesma semântica; (ii) classificou-as conforme as categorias; (iii) procedeu-se com a contagem da frequência dos termos encontrados; e (iv) realizaram-se inferências sobre o material, considerando manifestações escritas, verbais, bem como, o gestual e as expressões dos depoimentos em vídeos. Assim, estas etapas trouxeram maiores subsídios para compreender como os construtos pesquisados se apresentaram nos dados, buscando entender como o terrorismo afetou a imagem do destino sob a ótica dos turistas brasileiros.

A análise dos resultados é apresentada na seção seguinte e está estruturada inicialmente com as informações obtidas com os questionários abertos, seguindo com alguns trechos extraídos dos depoimentos em vídeos, e finalizando com uma síntese das informações que estão dando suporte às categorias definidas em princípio. 
Tabela 1 - Categorias

\begin{tabular}{|c|c|c|c|}
\hline Categorias & Definições & Referência Teórica & Construtos \\
\hline Sentimento & $\begin{array}{l}\text { Aptidão para sentir, disposição para se como- } \\
\text { ver, se impressionar, perceber e apreciar algo }\end{array}$ & $\begin{array}{l}\text { Choi, 2010; Goldman \& } \\
\text { Neubauer-Shani, 2017; Shaw, } \\
\text { 2000; Stern, 1999. }\end{array}$ & \\
\hline $\begin{array}{l}\text { Reação } \\
\text { (População) }\end{array}$ & $\begin{array}{l}\text { Comportamento de um ser vivo manifestado } \\
\text { em presença de um estímulo }\end{array}$ & $\begin{array}{l}\text { Frey, Luechinger \& Stutzer, } \\
2007 .\end{array}$ & Terrorismo \\
\hline $\begin{array}{l}\text { Política } \\
\text { Pública }\end{array}$ & $\begin{array}{l}\text { Programas, ações e atividades desenvolvidas } \\
\text { pelo Estado }\end{array}$ & $\begin{array}{l}\text { Estrada e Koutronas, 2016; Pi- } \\
\text { azza, 2013; Sonmez, } 1998 .\end{array}$ & \\
\hline Segurança & $\begin{array}{l}\text { Qualidade ou condição de quem ou do que está } \\
\text { livre de perigos, incertezas, assegurado de da- } \\
\text { nos e riscos eventuais; situação em que nada } \\
\text { há a temer }\end{array}$ & $\begin{array}{l}\text { Buigut, 2018; Liu \& Pratt, 2017; } \\
\text { Ritchie, 2004. }\end{array}$ & \\
\hline Xenofobia & $\begin{array}{l}\text { Desconfiança, temor ou antipatia por pessoas } \\
\text { estranhas ao meio daquele que as ajuíza, ou } \\
\text { pelo que é incomum ou vem de fora do país }\end{array}$ & $\begin{array}{l}\text { Bozzoli \& Muller, 2011; Casta- } \\
\text { nho-Silva, } 2018 .\end{array}$ & $\begin{array}{l}\text { Imagem do } \\
\text { Destino Turís- } \\
\text { tico }\end{array}$ \\
\hline $\begin{array}{l}\text { Impactos } \\
\text { (Turismo) }\end{array}$ & $\begin{array}{l}\text { Impressão ou efeito muito forte deixado por } \\
\text { certa ação ou acontecimento }\end{array}$ & 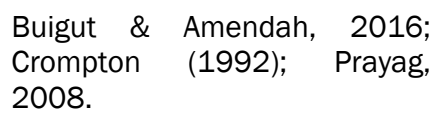 & \\
\hline
\end{tabular}

Fonte: Elaborado pelos autores

\section{ANÁLISE DOS RESULTADOS}

\subsection{Análise dos Questionários Abertos}

Nesta seção, são apresentados e analisados os dados coletados junto aos participantes, por meio da aplicação do questionário aberto. O questionário foi construído e disponibilizado aos turistas brasileiros, que presenciaram o incidente em Paris. Importante destacar que a discussão dos dados tomou como base os conceitos abordados na revisão da literatura, segunda seção deste trabalho, utilizados para orientar na interpretação dos elementos coletados. Além das perguntas direcionadas, a fim de não limitar os entendimentos e buscando perceber outras opiniões sobre o tema principal da ferramenta construída, como também para complementar as respostas do questionário, foi deixado um espaço ao fim da ferramenta permitindo que os respondentes ficassem livres em detalhar qualquer impressão sobre o ocorrido que não foi perguntado nas questões antecedentes.

No que diz respeito aos aspectos relacionados à questão inicial, a qual interrogava sobre o sentimento que os inquiridos perceberam ao saberem do atentado, a expressão "medo" foi encontrada em cinco das respostas, também foram visualizados sentimentos semelhantes ao primeiro, como "pavor", "pânico" e "angustia". Estas informações podem ser observadas em alguns trechos, das respostas dos participantes, que foram selecionados e apresentados a seguir:

\footnotetext{
"De desespero e medo de ter outro grupo de terrorista em outra parte da cidade fazendo outro atentado". Feminino, 34 anos, nutricionista.

“Negação, parecia mentira que algo assim tivesse ocorrido”. Feminino, 28 anos, estudante.

“Estávamos retornando para nossa residência [...] quando observamos que os painéis do metrô anunciavam risco de atentado [...]. Sentimos muito medo, porém era um sentimento diferente do medo da violência no Brasil. O sentimento era de indignação, mas também de incerteza [...]”. Masculino, 33 anos, professor universitário.
}

A proposição encontrada nesta relação foi sentimento, referente à capacidade de perceber algo. 0 sentimento principal das respostas confirma o julgamento etimológico do terrorismo, o qual afirma que é um ato que causa especialmente medo nos indivíduos (Sandler, 2015). Mesmo em sua diversidade de conceitos, opiniões e perspectivas diferentes (Samitas et al., 2018) e independente da motivação, sejam políticas, econômicas, sociais ou religiosas (Goldman \& Neubauer-Shani, 2017), os atos terroristas são usados para gerar impactos negativos nos locais. É possível perceber nas respostas dos participantes que o sentimento de medo prevalece nos indivíduos como uma reação inicial e principal, o que fortalece o alcance de um dos 
objetivos dos terroristas, que é prejudicar a imagem do local de destino para os turistas. Contudo, não apenas o medo é despertado, o sentimento de indignação também está presente.

Dois questionamentos seguintes quiseram entender como os brasileiros observaram as medidas de segurança adotadas pelo então presidente francês após os atentados e se estas foram suficientes.

“Ela (sic) foram necessárias para o momento, pelo menos para dar uma certa sensação de "segurança" Feminino, 34 anos, nutricionista.

“Achei coerente o controle de fronteiras, mas no toque de recolher não vi sentido". Feminino, 34 anos, engenheira.

"Sim, mas não a duração da ação, que foi muito longa e que atrapalhou a circulação de aviões na França". Feminino, 27 anos, conselheira RH/IT.

"Sim. Se nada fosse feito os atentados teriam continuado". Feminino, 46 anos, professora.

“Houve um endurecimento de um plano de segurança que já existia, chamado de Vigipirate. O Exército ocupou as ruas com mais força, houve a proibição de realização de passeatas e manifestação, e o plano de segurança (Vigipirate) foi fortalecido". Masculino, 33 anos, professor universitário.

Foram observadas 11 respostas afirmativas do total dos questionários, algumas com ressalvas, mas concordando positivamente com as ações de segurança. 0 terceiro questionamento pretendia medir se os residentes estrangeiros se sentiam seguros na capital francesa.

\footnotetext{
"Sim me sinto segura, mas como todo brasileiro sempre com cautela". Feminino, 34 anos, nutricionista.

“Sim, muito mais que nas capitais brasileiras”. Feminino, 32 anos, pesquisadora.
}

"Depende da região, depende do número de pessoas em volta, depende da hora do dia, depende do local, depende do tipo de transporte". Feminino, 29 anos, advogada.

Nestas duas perguntas anteriores, era intencionado medir a sensação de segurança dos inquiridos, se a entenderam como de qualidade ou não, ou seja, se eles se sentiram protegidos ou longe de algum perigo após os atos terroristas. As respostas dos participantes deixam evidente que o receio de um novo atentado fica presente no dia a dia da cidade, embora exista uma sensação de segurança com precaução. As ações mais rígidas de segurança trazem uma sensação de alento, mas não é uma situação fácil para o governo administrar no médio e longo prazo. Como observado por Pizza (2013), o monitoramento para evitar os atos terroristas estão aumentando após alguns anos de sucessivos ataques, isto pode ajudar na sensação de segurança por parte dos moradores e turistas.

Na quarta pergunta foi arguido como eles perceberam a reação dos franceses posteriormente aos atentados de 2015. Observam-se as respostas a seguir:

\footnotetext{
"Eles fizeram de tudo para mostrar que não iriam se intimidar. No outro dia, mesmo com parques e squares fechados, tinha muitas famílias na rua, crianças brincando nas calçadas. Achei corajoso". Feminino, 34 anos, engenheira.

"Nos primeiros dias todos ficaram em casa, Paris ficou vazia... em seguida todos retomaram suas vidas". Feminino, 28 anos, estudante.

“No dia seguinte não havia pessoas na rua, as que saiam ficavam assustadas. No geral, um misto de tristeza com revolta e uma atitude positiva de tentar se mostrar forte e não deixar ceder às ameaças terroristas". Feminino, 32 anos, pesquisadora.

"Houve uma comoção nacional, criaram uma rede de solidariedade para abrigar as pessoas que não conseguiram retornar para suas casas na noite do atentado. 0 dia seguinte foi de muitas homenagens às vítimas, mas percebemos em um parque (Grand Peloouse-Cité Internacionale Universitaire) que muitas famílias estavam com as suas crianças ocupando os espaços públicos, era uma forma de resistir contra a barbárie". Masculino, 33 anos, professor universitário.
}

A intenção neste momento foi averiguar sobre a reação da população nativa observada aos olhos de estrangeiros, neste caso os brasileiros, e assim medir as peculiaridades e valores do povo oriundo do local ao serem estimulados por algo trágico como o ato terrorista. Frey, Luechinger \& Stutzer (2007) alegam que após os atos, em determinado momento, há uma comoção pública seguida de uma reivindicação social aos governantes por medidas mais severas contra os articuladores e executores de eventos catastróficos. Os brasileiros que responderam aos questionários afirmaram o conceito anterior, relatando a vontade de se mostrarem fortes e unidos mesmo que em ambiente hostil de medo e insegurança. 
Objetivando entender sobre as ações públicas efetivadas pelos governantes parisienses, seguiram-se duas perguntas voltadas para as medidas de proteção realizadas pelo governo. A primeira questão interrogou se os moradores de qualquer nacionalidade, inclusive os próprios inquiridos, sentiram-se mais seguros ao longo do tempo.

\footnotetext{
"Não sei precisar, acho que depende da pessoa, ou do grupo de pessoas. Tem gente que se sente segura com o exército armado nas ruas, tem gente que não". Feminino, 34 anos, engenheira.

“Não sei, eu não me senti insegura. Questão cultural. Na verdade, ter soldados o tempo inteiro circulando onde civis ficam dá um sentimento maior de insegurança". Feminino, 27 anos, conselheira $\mathrm{RH} / \mathrm{IT}$.

"Sim, muito mais policiamento e controle na entrada de locais de muita circulação". Feminino, 32 anos, pesquisadora.

"Não. É praticamente impossível prever onde um atentado vai acontecer. E colocar militares em todo lugar causa mais pânico". Feminino, 35 anos, fotógrafa.

"Acho que todos sabem que não estão seguros, mas levam suas vidas normalmente". Feminino, 35 anos, guia conferencista.
}

A segunda pergunta examinava sobre as ações realizadas, quais seriam para evitar novos possíveis ataques.

\footnotetext{
"A França está seguindo o plano Vigipirate, onde a vigilância é redobrada em todos os lugares públicos e investigando as pessoas que possuem um perfil suspeito. Não penso que haja algo a mais que isso que possa melhorar a situação". Feminino, 34 anos, nutricionista

“Talvez maior controle de fronteiras. Os terroristas eram cidadãos europeus, podem ir e vir sem controle nenhum. Acho que o governo poderia monitorar mais a população também, principalmente aqueles com registro de radicalização". Feminino, 34 anos, engenheira.

"Mais polícia nas ruas e deveria ter mais controle na imigração e nas fronteiras". Feminino, 25 anos, arquiteta.

"Mais investigação de inteligência". Feminino, 34 anos, jornalista.

“Acho que a política internacional é o maior problema". Feminino, 35 anos, guia conferencista.
}

Embora exista uma dificuldade latente em evitar as ações terroristas por parte dos governantes, os programas desenvolvidos pelo Estado buscaram, conforme os trechos acima, principalmente limitar e evitar outros ataques tanto antes de estarem confirmados quanto depois, corroborando com as idéias de Estrada e Koutronas (2016). A estratégia de colocar uma força militar mais ostensiva nas ruas não é sustentável no médio e longo prazo, porque não é viável ter militares em cada lugar que seria um possível alvo de terroristas. Além disso, isso pode também causar uma sensação de insegurança na população. Assim, o serviço de inteligência do país atuou para evitar novos ataques, o que é confirmado nas falas acima como também confirmado pelo professor universitário quando na parte complementar na ferramenta, ele informou:

\footnotetext{
"Nos dias que antecederam os atentados, os números de avisos do Plano de Vigipirate se intensificaram. Acredito que a polícia francesa por meio das suas investigações, já tinha uma dimensão da possibilidade de um atentado [...]". Masculino, 33 anos, professor universitário.
}

Além disto, Lepp e Gibson (2008) sugerem que a divulgação intensiva dos atos pela mídia, mais pessoas se sentem empoderadas em se juntar aos grupos terroristas, deixando-os mais fortes e aumentando a frequência de ataques. Além disso, quanto mais a mídia divulga os atos ajuda a propagar os ideais defendidos pelos grupos terroristas. Percebe-se, assim, mais uma dificuldade para as autoridades para evitar as ações do terrorismo, por causa do conflito de interesses dos agentes envolvidos, terroristas, governo e mídia. Desta forma, conforme sugerido por Pizza (2013), as políticas de segurança precisam ser mais severas e com maior monitoramento, focando principalmente na investigação que anteveja os atos.

Outra questão visava avaliar se as medidas de segurança, através das políticas públicas, interferiram na vida de estrangeiros residentes na França, como também na dos turistas.

"Provavelmente, toda ação de controle atinge estrangeiros, principalmente se esses não tiverem o estereótipo europeu branco e louro”. Feminino, 34 anos, engenheira.

"Sim, depende da sua origem. Honestamente, para os turistas latinos não mudou muita coisa, mas pros (sic) imigrantes e turistas de origem muçulmana, talvez tenha mudado. Não saberia te dizer". Feminino, 27 anos, conselheira $\mathrm{RH} / \mathrm{IT}$. 
“É possível que tenha aumentado o preconceito com imigrantes de origem Árabe e há um controle maior nos aeroportos". Feminino, 32 anos, pesquisadora.

“É uma situação diferente para quem vive num país sem terrorismo, tal como o Brasil, mas não creio que interfira na vida do visitante". Feminino, 46 anos, professora.

Como na questão anterior, pretendeu-se analisar como os brasileiros sentiram o tratamento aos estrangeiros ou a determinados grupos étnicos, se houve alguma mudança em seguida aos atentados.

\footnotetext{
“Sempre houve tratamento diferenciado, talvez após os atentados os preconceituosos só acharam a desculpa "perfeita"”. Feminino, 34 anos, engenheira.

“Não, preconceito sempre existiu em relação aos muçulmanos, mas em Paris, a mistura cultural é tão grande que não se vê muito racismo ou preconceito claro". Feminino, 27 anos, conselheira RH/IT.

“Sim, principalmente contra árabes e negros”. Feminino, 35 anos, guia conferencista.

"Principalmente com os islâmicos, os olhares, a desconfiança e a xenofobia. Tínhamos um amigo muçulmano que sofria com o que se denomina de islamofobia". Masculino, 33 anos, professor universitário.
}

Com ataques ainda mais planejados e querendo atingir alvos que ganhem mais comoção pública, há uma intensificação em agirem em locais com vítimas mais fáceis e vulneráveis. Estes ambientes geralmente são públicos e com grande fluxo de pessoas, como os pontos atacados (Tarlow, 2006). Isto também facilita que um número maior de nacionalidades seja atingido, como foi o caso do terror em Paris. Nestes casos, a xenofobia torna-se visível e de maior abrangência depois de assumidas ou descobertas as nacionalidades dos terroristas. A xenofobia é conceituada pela aversão pelo que é diferente ou ainda ódio ou medo por pessoas estranhas a localidade dos nativos (Molina, Gómez \& Consuegra, 2010). As duas perguntas anteriores pretenderam descobrir se esta fobia já era identificada pelos inquiridos antes dos atos terroristas ou se caso não existisse anteriormente surgiram a partir dos ataques. Os atos estudados foram promovidos por questões já relacionadas a este aspecto, quando povos muçulmanos sofreram discriminação e exclusão social anos antes do ocorrido (Bozzoli \& Muller, 2011).

Em outro momento do questionário, almejou-se medir se as pessoas continuavam visitando Paris ou eles notaram uma diminuição do fluxo em algum período depois dos atentados.

\begin{abstract}
“Imediatamente eu notei uma diminuição da quantidade de asiáticos na cidade, mas agora tudo voltou ao normal". Feminino, 34 anos, nutricionista.

"O turismo voltou a se normalizar um ano após o atentado, antes disso houve uma crise no setor". Feminino, 32 anos, pesquisadora.

“Eu trabalho com turismo e nos primeiros meses após os atentados foi incrível a baixa no fluxo de turistas. E foi a minha pior temporada de trabalho em 2016". Feminino, 35 anos, guia conferencista.

“[...] os números de visitantes caíram drasticamente. Porém a partir de fevereiro de 2016 percebi que a cidade passou a receber um fluxo maior de turistas [...]”. Masculino, 33 anos, professor universitário.
\end{abstract}

A intenção era avaliar se os impactos de um ato de tamanha magnitude, como um ataque terrorista, trariam efeitos substanciais por parte da demanda turística, já que a atividade do turismo pode sofrer impactos negativos por vários motivos (Liu \& Pratt, 2017) e um dos principais efeitos é na curva equilibrada da oferta e da demanda de uma localidade turística (Walters, Wallin \& Hartley, 2018). Em 2015, com o atentado terrorista na França, o impacto se deu por uma ação humana, pelo número de mortes e pela sequência de atentados, e interferiu instantaneamente com cancelamentos de voos e em meios de hospedagem (Seraphin, 2017), bem como, em um retorno mais lento do consumidor (Tarlow, 2006). Apesar do período para recuperação da imagem do destino, com a pausa dos ataques e políticas mais severas de segurança, não houve um impacto muito nocivo no turismo, pois com cerca de um ano houve a normalização do fluxo turístico como declarados pelos entrevistados.

Paris e seus habitantes tiveram um importante papel para reconstrução da imagem como destino turístico forte, isto é entendido nas declarações:

"A imagem dos atentados para os franceses foi como um atentado ao estilo de vida francês (liberté) e por isso por mais que existam medidas de segurança na cidade, eu sinto que os cidadãos fazem questão de mostrar que não irão se abater". Feminino, 34 anos, nutricionista. 
"Os parisienses não curtem mídia sensacionalista e não alimentam o medo de atentado, vivem a vida normalmente. Sentem-se às vezes controlados demais com as atuais medidas de segurança. Privacidade e liberdade são muito relevantes por aqui". Feminino, 32, pesquisadora.

"O terrorismo funciona pq (sic) todos têm a impressão de que escapou por pouco. Mata alguns, mas atinge toda a população. Os parisienses fazem esforços para mostrar que não estão com medo". Feminino, 34 anos, jornalista.

Mesmo assim alguns estrangeiros sentem momentos de insegurança, mesmo anos depois, como é percebido na declaração da técnica de laboratório de 26 anos: "Fui convidada a um show em Bercy porém não fui porque achei que ia morrer" e da engenheira de 27 anos que afirmou "Só acho interessante ressaltar que não me sinto mais segura e principalmente que não frequento mais lugares aberto ao público sem entrada controlada".

\subsection{Análise dos Depoimentos dos Vídeos}

A utilização dos depoimentos ocorreu pela necessidade de conferir confiabilidade e validade da pesquisa através da triangulação dos dados. Assim, mesmo com escassez de material na plataforma pesquisada depois de quase dois anos e meio após os acontecimentos, foram selecionados depoimentos de turistas brasileiros veiculados nos dois dias subsequentes aos atentados. Essa proximidade faz-se fundamental para garantir que um maior número de sentimentos e reações possa ser revelado pelo discurso destes turistas, trazendo mais elementos a serem analisados, sem que houvesse perda das memórias devido ao tempo decorrido (Creswell, 2016). Logo, o depoimento em vídeo não traz somente a fala do entrevistado, mas expressões, silêncios e gestos para compor a análise com o intuito de minimizar impactos e distorções da edição das imagens.

Assim, ao proceder com a análise dos mesmos, foi possível identificar a presença de características semeIhantes aos questionários, conforme se verifica nos trechos transcritos a seguir:

“[...] as pessoas se assustaram, se criou um clima de pânico e voltaram correndo para dentro do estádio. Aí, todo mundo é claro se assustou e invadiu o campo, o gramado". Feminino, jornalista.

“[...] o pânico pegou eu acho que entre dez a quinze minutos do fim do jogo. As pessoas começaram a querer sair, e foi aí onde começou a rolar o famoso boca a boca. O pessoal dizendo: "não estão liberando a saída!", “o que é que está acontecendo?”. Pior do que o barulho de bombas, de explosão, o que seja, é você ver oitenta mil pessoas correndo, passando umas por cima das outras. É como se fosse uma corrida para a morte [...]". Masculino, estudante.

"O momento mais assustador para a gente foi exatamente quando a gente estava na Gare Du Nord, estação de trem em que a gente mudaria para o metrô, e a polícia começou a vir correndo e dizendo saiam logo da estação, saiam correndo da estação [...]" Masculino, sociólogo.

Os recortes acima revelam sentimentos de pânico, medo da morte e susto, novamente fica explícita uma instabilidade social a partir de atos violentos, todas essas características presentes em conceitos e definições sobre o terrorismo, ratificadas por estudos como o de Frey, Luechinger \& Stutzer (2007), Choi (2010), Fortna (2015). Outros depoimentos demonstraram a necessidade de se sentirem seguras

\footnotetext{
"Quando a gente saiu, eu perguntei ao rapaz ali fora e ele falou que tinha sido um ataque terrorista do lado de fora do estádio. Aí, a polícia pediu para todo mundo entrar para o campo e esperar aqui até uma segunda ordem". Masculino, contador.
}

“Estávamos a uns, sei lá, 500 metros, meio quilômetro, um quilômetro de distância do bar que foi metralhado, tinha gente do nosso grupo que estava no bar ao lado e se escondeu atrás do balcão". Masculino, fotógrafo.

“[...] eu comecei a escutar uns barulhos, ele falou: é tiro, é tiro! Nem sabia que era atentado. A gente se escondeu atrás do balcão. Aí, quando eu saí do bar, que abri a porta tinha um monte de gente machucada e morta na rua". Masculino, publicitário.

A segurança é um atributo que compõe as impressões coletivas, sentimentos, crenças e percepções do turista na formação da imagem do local (Stylidis \& Cherifi, 2018), podendo interferir no processo de escolha do destino (Crompton, 1979). Assim, uma questão como esta poderá levar a uma instabilidade da atividade turística, causando diminuição na demanda e até desemprego (Parra, 2015), podendo culminar na perda da atratividade local (Pizam \& Fleischer, 2002), além de aumentar os custos com segurança, que são repassados aos turistas (Buigut, 2018), e os preços mais altos poderão dificultar a normalização da demanda. 
O último aspecto dos depoimentos em que se identificou correspondência com os questionários: a xenofobia, como é possível perceber no excerto seguinte:

“[...] as pessoas que são árabes ou tem cara de árabe, como é o meu caso. Essas pessoas estão muito apreensivas de voltar a sair na rua pela pressão social que vai se exercer, não só pelas pessoas que tão infladas pelo ódio e pelo medo, que gera o preconceito, mas também pelas forças de segurança que devem agir para coibir os suspeitos de terrorismo”. Masculino, jornalista.

Os elementos presentes no trecho acima se assemelham aos encontrados nos questionários abertos, e demonstram que existência da xenofobia é anterior aos acontecimentos, atuando como fator para a discriminação destes grupos religiosos, e intensificado por políticas governamentais intolerantes como argumentam Bozzoli e Muller (2011) e Castanho-Silva (2018).

\subsection{Síntese das Categorias}

Nos depoimentos foi possível perceber a presença de três categorias: sentimento, segurança e xenofobia. $\mathrm{Na}$ categoria sentimento, a palavra mais recorrente são aquelas relacionadas à morte, totalizando oito repetições (50\%), em geral, proveniente do medo e da exposição a uma situação impossível de controlar (Englund \& Stohl, 2016). As emoções presentes nas falas eram prioritariamente negativas, demonstrando os estados de pânico, desespero e pavor (Liu \& Pratt, 2017; Buiguit, 2018). A palavra feliz foi utilizada de modo a indicar a realização pelo distanciamento do local dos atentados. Embora a palavra polícia tenha sido aplicada cinco vezes $(41,7 \%)$ na categoria segurança, seu uso trazia um reflexo desfavorável, pois surgiram em momentos de incerteza. Já oito (25\%) citações exprimiam a necessidade de proteção. 0 receio por reações xenófobas com a etnia árabe ou com características físicas similares esteve presente em duas (50\%) das alusões em uma das categorias identificadas. Uma síntese das palavras em cada categoria pode ser conferida na Tabela 2.

\begin{tabular}{|c|c|c|c|}
\hline Categorias & Depoimentos & Frequência & Percentual \\
\hline \multirow{13}{*}{ Sentimento } & As pessoas se assustaram & \multirow{4}{*}{4 vezes } & \multirow{4}{*}{$25 \%$} \\
\hline & A gente se assustou & & \\
\hline & Todo mundo é claro se assustou & & \\
\hline & O momento mais assustador & & \\
\hline & Se criou um clima de pânico & 2 vezes & $125 \%$ \\
\hline & O pânico pegou entre 10 a 15 minutos & $\angle$ ve $\angle \mathrm{e} s$ & $\perp<, 5 \%$ \\
\hline & Foi bem desesperador & $1 \mathrm{vez}$ & $6,25 \%$ \\
\hline & Eu vi a morte & & \multirow{5}{*}{$50 \%$} \\
\hline & Era uma corrida para a morte & \multirow{4}{*}{8 vezes } & \\
\hline & Vive e morre, morre e vive & & \\
\hline & $\begin{array}{l}\text { Corrida para a morte } \\
\text { Eu vou morrer, eu vou morrer }\end{array}$ & & \\
\hline & Gente machucada e morta na rua & & \\
\hline & Estou feliz porque voltei para o Brasil & $1 \mathrm{vez}$ & $6,25 \%$ \\
\hline \multirow{11}{*}{ Segurança } & Foi proibido pela polícia & & \\
\hline & $\begin{array}{l}\text { A polícia começou a vim correndo e dizia saiam logo da } \\
\text { estação }\end{array}$ & & \\
\hline & $\begin{array}{l}\text { A polícia estava dizendo para a gente sair correndo } \\
\text { A polícia pediu para todo mundo entrar }\end{array}$ & 5 vezes & $41,70 \%$ \\
\hline & Forças de segurança devem agir para coibir os suspei- & & \\
\hline & tos & \multirow{5}{*}{4 vezes } & \\
\hline & Dava para ouvir alguns tiros & & \multirow{4}{*}{$33,30 \%$} \\
\hline & Ele falou: é tiro, é tiro & & \\
\hline & Do bar que foi metralhado & & \\
\hline & Se esconder atrás das cadeiras & & \\
\hline & Se escondeu atrás do balcão & 3 vezes & $25 \%$ \\
\hline & A gente se escondeu atrás do balcão & & \\
\hline \multirow{3}{*}{ Xenofobia } & As pessoas que são árabes ou têm cara de árabes & 2 vezes & $50 \%$ \\
\hline & Infladas pelo ódio e pelo medo & $1 \mathrm{vez}$ & $25 \%$ \\
\hline & Gera o preconceito & $1 \mathrm{vez}$ & $25 \%$ \\
\hline
\end{tabular}

Os questionários apresentaram todas as categorias semânticas escolhidas para o estudo. Os turistas brasileiros em Paris, em seis dos questionários respondidos, afirmaram sentir medo diante do ocorrido. Este é o 
sentimento mais prevalente em praticamente todos os turistas após os atentados (Buigut \& Amendah, 2016; Kiliçlar, Usakli \& Tayfun, 2017). Os sentimentos, tais como pânico, pavor, angústia e indignação indicaram a reação daqueles próximos aos ataques ou em lugares onde estes aconteceram. Outros indivíduos relatam sobre a impotência, a apatia, a incerteza e a negação diante dos fatos, e por fim, a tristeza pelas vidas perdidas.

Já a reação da população francesa, na visão dos brasileiros, foi de choque e medo inicialmente. Esta reação dos franceses também foi percebida nos estudos de Seraphin (2017) e Nevalsky (2015). Alguns participantes afirmaram "no dia seguinte eles fizeram questão de sair, ir para os cafés e mostrar que os extremistas muçulmanos não iriam conseguir disseminar o terror entre os franceses". A partir deste e outros fragmentos trazidos na seção anterior, se percebe o despertar de um sentimento nacionalista (Estrada \& Koutronas, 2016), de não se conformar com os ataques, estas reações foram identificadas em nove (64\%) dos questionários.

Em relação à segurança, oitos (57\%) dos respondentes não se sentiram seguros apesar das ações governamentais (Castanho-Silva, 2018), enquanto, dois questionários (14\%) afirmaram que apesar das medidas preventivas os atos terroristas são imprevisíveis, e dificilmente o governo conseguirá prenunciar um novo ataque. Estas informações mostram o quanto é difícil controlar as ações terroristas e como os turistas sentem-se apreensivos com isso (Samitas et al., 2018). Quanto às medidas emergenciais adotadas no âmbito da política pública, onze (79\%) dos brasileiros pesquisados demonstraram concordância, os restantes indicaram desconforto com algumas ações, como por exemplo, o toque de recolher.

Já no que tange à continuidade das ações de políticas públicas, as respostas já apresentaram maior variabilidade, não havendo harmonia entre as práticas adotadas. Um total de seis respondentes apontou a necessidade de maior controle de fronteiras como se percebe no recorte: "os terroristas eram cidadãos europeus, podem ir e vir sem controle nenhum". Outros declaram a política internacional francesa como a maior causa do ocorrido, ou seja, acreditam que evitar os conflitos com os "países islâmicos" seria a solução. Outros turistas sugerem maiores investimentos na área de inteligência e acordos de cooperação internacional para restringir as ações terroristas. Estes achados estão em consonância com os estudos de Saha e Yap (2014) em que propõem políticas internacionais que visem diminuir os conflitos entre os países, mais especificamente com os países islâmicos.

Outro fator investigado neste estudo foi a presença de xenofobia nas relações entre franceses e estrangeiros, as respostas foram equilibradas, sete pessoas acharam não interferir, enquanto sete pessoas acreditam nesta interferência. Logo, apesar das afirmações de alguns turistas, e levando em consideração medidas anteriores do governo francês como a proibição do uso do niqab, esta percepção pode não representar uma realidade social. Esta declaração equivocada pode ser devido a um distanciamento do turista ou até mesmo por não possuir características étnicas similares aos povos árabes (Castanho-Silva, 2018).

Ao avaliar uma possível redução no fluxo de turistas buscou-se medir os impactos, cinco (35\%) respondentes afirmaram ter ocorrido uma diminuição nos primeiros meses após os ataques, enquanto nove (64\%) declaram não acreditar na redução de visitantes na cidade. Assim, a França apresentou uma situação peculiar em 2015, pois se tornou cenário de muitos atentados consecutivos, e estas ações tiveram um reflexo imediato na atividade turística. 0 país apresentava uma escalada nos números do turismo internacional desde 2010, e em 2016 o setor turístico movimentou a receita de U\$ 42,5 milhões, uma baixa de 5,34\% em relação a 2015. Já quanto às chegadas internacionais, apesar da redução de 0,9\% nos índices, a França terminou 2016 no ranking dos dez países mais visitados do mundo, com um fluxo de 82,6 milhões de turistas, e com previsão de recuperação para 2017 (UNWTO, 2017). 0 impacto existiu de maneira moderada diante dos números apresentados, corroborando a percepção dos turistas brasileiros ao afirmarem não perceberem redução no fluxo de visitantes em Paris.

Na perspectiva da imagem do destino, a insegurança foi um estímulo presente nas respostas, apesar das políticas públicas e do policiamento mais ostensivo nas fronteiras. Entretanto, a imprevisibilidade dos ataques anuncia qualquer lugar como alvo hipotético não somente Paris, ou seja, deixar de visitá-la não traz a certeza do distanciamento do perigo. Esse resultado poderia apresentar-se de forma divergente em outra 
localidade, mas Paris possui uma imagem consolidada através dos anos - a Cidade Luz - uma marca positiva construída e fixada no turismo internacional e isso a torna diferente de outras cidades e/ou de outros produtos (Blain, Levy \& Ritchie, 2005; Son, 2005).

\section{CONSIDERAÇÕES FINAIS}

O terrorismo contemporâneo não ambiciona apenas o medo indômito, o pânico, o terror, mas a derrubada de um imperialismo cultural (Hoffman, 1998; Samitas et al., 2018). O fenômeno do turismo se intensificou no decorrer dos anos, pois permite um contato momentâneo com o díspar sem a exigência da aculturação ou da hibridização como declara Wainberg (2005), o turista possui um olhar voyeur e dissimulado numa falsa fusão antropológica, e nesta comunicação intercultural precária o retorno às crenças e valores é mantido inabalado. Logo, na sociedade do hiperespetáculo, do divertimento e da economia de experiências, o turismo é o astro principal e quando as cidades se comercializam como em um show business (Lipovetsky \& Serroy, 2015), elas se tornam o palco de atentados. Os extremistas desejam uma maior atenção da mídia, e sem um palco eles não existiriam.

A Noite do Terror em Paris computou um total de oito ataques, destacando as bombas no Stade de France, localizado no distrito de Saint Denis próximo a Paris; tiroteio contra clientes nos restaurantes Le Carillon, Le Petit Cambodge, La Belle Equipe e Café Bonne Biere; um homem-bomba suicida explodiu contra o restaurante Comptoir Voltaire; e a ação de três suicidas, atirando dentro da boate Bataclan, onde acontecia um show da banda Eagles of Death Metal. Foram mortas 93 pessoas e outras 217 ficaram feridas no ataque. Além disso, pelo menos 20 civis foram pegos como reféns por duas horas (GTD, 2017). 0 presente estudo contribuiu no entendimento entre a relação dos ataques acima descritos com a imagem da cidade de Paris pela visão de turistas brasileiros, e quais as consequências destas ações na demanda turística na percepção destes indivíduos.

O objetivo central desta pesquisa foi avaliar o impacto dos atos terroristas na imagem de destino da cidade de Paris por turistas brasileiros. Este objetivo foi atingido com a identificação das informações de que os turistas brasileiros compartilham dos mesmos sentimentos de insegurança dos moradores e visitantes na cidade onde ocorreram os atentados, mas que isso não diminuiu a vontade de permanecer ou voltar à cidade de Paris. Além disso, as medidas mais ostensivas adotadas pelo governo não causaram desconforto ao ponto de ser um motivo de não retornar a cidade, pelo contrário, existe uma cooperação por parte dos moradores e turistas nas ações para que se evitem atentados com maiores proporções de pessoas atingidas, uma vez que é praticamente impossivel impedir os atos terroristas. Assim, é plausível afirmar que o terrorismo está afetando minimamente as atividades turísticas da cidade de Paris, e que os turistas brasileiros não mudaram a vontade de visitar a cidade, mesmo diante deste contexto de medo.

Diante disto, muito da disputa cultural entre a França e os islâmicos se deve ao orientalismo, que se resume em um estilo de dominação ocidental europeia sobre o oriente, colonizando-o, reestruturando-o e passando a ter autoridade sobre ele. Esse conceito se inicia com o colonialismo britânico e francês sobre a Índia e as terras bíblicas, e após a Segunda Guerra passa a dominar o oriente influenciado pelos mesmos critérios. Entretanto, essa troca não é unilateral, o oriente passa a definir e integrar a civilização e a cultura da Europa (Said, 1990). Por isso, políticas xenófobas adotadas pelo governo francês desconsideram a existência de uma miscigenação cultural da sociedade francesa oriunda de sua própria política colonizadora, e apesar de islâmicos também são franceses e estão em sua casa, sua terra.

Segundo Oz (2004), um fanático é um altruísta que deseja redimi-lo da influência de uma cultura ocidental contraria as suas ideologias. Logo, a cura para este comportamento está no humor, no ceticismo e na argumentatividade, na qual se pretende superar estes ideais com algo melhor. Estes elementos estão presentes nas crônicas de Charbonnier (2015) (mais conhecido como Charb), ao tratar com humor a laicidade, o ceticismo dos ateus e, até mesmo, o paradoxo entre a crença e o fanatismo religioso.

0 uso do terror a fim de expandir ideais particulares não irá desaparecer, mesmo tendo resultados inexpressivos sobre a intenção das pessoas para retornarem a cidade afetada. Infelizmente, a cada ano vê-se justamente o contrário, o aumento das atrocidades e desenvolvimento de melhores métodos de atingirem os objetivos das causas terroristas. Diante disto, vale a reflexão sobre como a mídia poderia explorar as notícias 
sem que o capital financeiro estivesse sobreposto ao humano, já que é confirmado baseado nas teorias, que sem repercussão, dificilmente, os ataques se expandissem tanto. Faz-se necessário criar métodos mais éticos e gestão da informação mais democrática, segura e menos sensacionalista. 0 combate aos ataques é possível, mas a guerra não é o meio mais adequado de rechaçá-lo. Caminhos pacíficos para o diálogo podem surgir através da diplomacia internacional, e serão meios mais eficazes para combater as práticas terroristas (Saint-Pierre, 2015).

Por fim, o respeito do mundo acadêmico e dos formadores de opinião pelos termos "terrorismo" e "terrorista", e não somente a reprodução acrítica destes, construiria um alicerce para os debates e não aumentaria o desconforto e o preconceito. Atitudes como estas alargariam o diálogo, pois na ausência de uma anuência entre as nações, quando se cria um mal absoluto para propor um remédio mais próximo da doença do que da cura. Num mundo onde a guerra prevalece à política por outros meios, a solução seria acreditar nos indivíduos, investir na construção de um sentimento de responsabilidade e hospitalidade com o próximo, sem restringir a responsabilidade moral pelo outro e renunciar a fronteira entre as culturas (Bauman, 2017). Porém, esta discussão ainda é incipiente e precisa de mais debate sobre a temática.

A pesquisa apresentou algumas limitações. Primeiramente, a variedade de conceitos envolvendo o terrorismo, pois a ausência desta definição permite enquadrá-lo em muitas situações. Contudo, a amarração de um conceito colocaria algumas ações dos Estados, supostamente legais, no arcabouço do terrorismo. Num segundo plano, a impossibilidade de entrevistar diretamente os turistas participantes da pesquisa, pois talvez esta prática fornecesse uma gama maior de informações para o cruzamento da fundamentação teórica com os resultados. Por último, a distância dos acontecimentos, pois como os indivíduos foram essencialmente um dos pilares do estudo, é normal o esquecimento (perda) de alguns detalhes com o passar do tempo (Creswell, 2016).

Outra possível investigação poderá abordar as perspectivas dos nativos da Cidade Luz, buscando identificar o sentimento e o olhar do morador sobre abrir as portas de sua cidade para fins turísticos, mesmo deixando margem para perigos como é o exemplo do terrorismo. Uma segunda proposta de investigação seria conduzir um estudo tomando por objeto outra destinação turística cena de ataques, mas que ainda não possua uma imagem positiva tão amplamente semeada na mentalidade coletiva como Paris.

\section{REFERÊNCIAS}

Abadie, A. (2006). Poverty, political freedom and the roots of terrorism. American Economic Review, 96(2), 50-56. https://doi.org/10.1257/000282806777211847

Amorim, E., Soares, C. \& Tarlow, P. (2015). Segurança: um desafio para os setores de lazer, viagens e turismo. 1. ed. Portugal: Instituto Politécnico de Tomar.

Araña, J. E. \& León, C. J. (2008). The impact of terrorism on tourism demand. Annals of Tourism Research, 35(2), 299-315. https://doi.org/10.1016/j.annals.2007.08.003

Baloglu, S. \& Mccleary, K. (1999). A Model of Destination Image Formation. Annals of Tourism Research, 26(4). https://doi.org/10.1016/S0160-7383(99)00030-4

Bardin, L. (2011). Análise de conteúdo. São Paulo: Edições 70 Brasil.

Bastida, U. \& Huan, T. C. (2014). Performance evaluation of tourism websites' information quality of four global destination brands: Beijing, Hong Kong, shanghai, and Taipei. Journal of Business Research, 67(2), 167-170. https://doi.org/10.1016/j.jbusres.2012.10.008

Bauer, M. W. (2002). Análise de conteúdo clássica: uma revisão. In: Bauer, M. W. \& Gaskell, G. (Eds.) Pesquisa qualitativa com texto, imagem e som: um manual prático. Petrópolis: Vozes.

Bauman, Z. (2017). Estranhos à nossa porta. Rio de Janeiro: Zahar.

Beerli, A. \& Martin, J. D. (2004). Factors influencing destination image. Annals of Tourism Research, 31(3), 657-681. https://doi.org/10.1016/i.annals.2004.01.010

Bergen, P. (2001). Holy war, inc.: inside the secret world of Osama Bin laden. New York: The Free Press.

Bergesen, A. J., \& Han, Y. (2005). New directions for terrorism research. International Journal of Comparative Sociology, 46(1-2), 133-151. https://doi.org/10.1177/0020715205054474 
Blain, C., S. E. Levy \& Ritchie, B. (2005). Destination branding: Insights and practices from destination management organizations. Journal of Travel Research, 43(4), 328-338. https://doi.org/10.1177/0047287505274646

Bozzoli, C., Müller, C. (2011). Perceptions and attitudes following a terrorist shock: Evidence from the UK. European Journal of Political Economy, 27, S89-S106. https://doi.org/10.1016/j.ejpoleco.2011.06.005

Buigut, S. \& Amendah, D. D. (2016). Effect of terrorism on demand for tourism in Kenya. Tourism Economics, 22(5). https://doi.org/10.5367/te.2015.0467

Buigut, S. (2018). Effect of terrorism on demand for tourism in Kenya: A comparative analysis. Tourism and Hospitality Research, 18(1). https://doi.org/10.1177/1467358415619670

Burke, J. (2007). Al-Qaeda: a verdadeira história do radicalismo islâmico. Rio de Janeiro: Jorge Zahar Editor.

Castanho-Silva, B. (2018). The (non) impacto of the 2015 Paris terrorist attack on political attitudes. Personality and Social Psychology Bulletin, In press. https://doi.org/10.1177/0146167217752118

Chabonnier, S. (2015). Pequeno tratado da intolerância. São Paulo: Planeta.

Chen, C.C., Lin, Y.H., Gao, J., \&Kyle, G. (2015). Developing a market-specific destination image scale: A nomological validation approach. Tourism Analysis, $20,12$. https://doi.org/10.3727/108354215X14205687167428

Chi, C. G. \& Qu, H. (2008). Examining the structural relationships of destination image, tourist satisfaction and destination loyalty: An integrated approach. Tourism Management, 29, 624-636. https://doi.org/10.1016/j.tourman.2007.06.007

Choi, S. W. (2010). Fighting terrorism through the rule of law? Journal of Conflict Resolution, 54(6), 940-966. https://doi.org/10.1177/0022002710371666

Chon, K. S. (1991). Tourism destination image modification process: Marketing implications. Tourism Management 12(2), 68-72. https://doi.org/10.1016/0261-5177(91)90030-W

Creswell, John W (2016). Projeto de pesquisa: métodos qualitativo, quantitativo e misto. Porto Alegre: Artmed.

Crompton, J. (1979). An assessment of the image of Mexico as a vacation destination and the influence of geographical location upon that image. Journal of Travel Research, 17(4), 18-43. https://doi.org/10.1177/004728757901700404

Crompton, J. (1992) Structure of vacation destination choice sets. Annals of Tourism Research, 19, 420-434. https://doi.org/10.1016/0160-7383(92)90128-C

Cronin, A. K. (2002). Rethinking sovereignty: American strategy in the age of terrorism. Survival, 44(2), 119139. https://doi.org/10.1093/survival/44.2.119

Denzin, N. K. \& Lincoln, Y. S. (2006). Introdução: A disciplina e a prática da pesquisa qualitativa. In: Denzin, N. K. \& Lincoln, Y. S. (Orgs.). O planejamento da pesquisa qualitativa: teorias e abordagens. Porto Alegre: ArtMed.

Drakos, K. \& Kutan, A. M. (2003). Regional effects of terrorism on tourism in three Mediterranean countries. Journal of Conflict Resolution, 47, 621-641. https://doi.org/10.1177/0022002703258198

Echtner, C. M. \& Ritchie, J. R. B. (1991). The meaning and measurement of destination image. Journal of Tourism Research, 2(2), 2-12.

Embacher, J. \& Buttle, F. (1989) A repertory grid analysis of Austria's image as a summer vacation destination. Journal of Travel Research, 27(3), 3-7. https://doi.org/10.1177/004728758902700302

Englund, S. \& Stohl, M. (2016). Construction of terrorismo. Perspectives on Terrorism, 10(3).

Estrada, M. A. R. \& Koutronas, E. (2016). Terrorist attack assessment: Paris November 2015 and Brussels March 2016. Journal of Policy Modeling, 38(3), 553-571. https://doi.org/10.1016/j.jpolmod.2016.04.001

Fortna, V. P. (2015). Do terrorists win? Rebels' use of terrorism and civil war outcome. International Organization, 69(3), 519-556. https://doi.org/10.1017/S0020818315000089

Franco, M. L. P. B. (2007). Análise do conteúdo. Brasília: Líber Livro.

Frey, B., Luechinger, S., \& Stutzer, A. (2007). A calculating tragedy: Assessing the costs of terrorism. Journal of Economic Surveys. 21(1), 1-24. https://doi.org/10.1111/j.1467-6419.2007.00505.x 
Freytag, A., Krüger, J. J., Meierrieks, D. \& Schneider, F. (2011). The origins of terrorism: Cross-country estimates of socio-economic determinants of terrorism. European Journal of Political Economy, 27, S5-S16. https://doi.org/10.1016/i.ejpoleco.2011.06.009

Foroudi, P., Akarsu, T. N., Ageeva, E., Foroudi, M. M., Dennis, C. \& Melewara, T. C. (2018). Promising the dream: Changing destination image of London through the effect of website place. Journal of Business Research, 83, 97-110. https://doi.org/10.1016/j.jbusres.2017.10.003

Gallarza, M. G, Saura, I. G, \& García, H. C. (2002). Destination image: Towards a conceptual framework. Annals of Tourism Research, 29(1), 56-78. https://doi.org/10.1016/S0160-7383(01)00031-7

Goldman, O. S. \& Neubauer-Shani, M. (2017). Does international tourism affect transnational terrorism. Journal of Travel Research, 56(4). https://doi.org/10.1177/0047287516649059

GTD (2017, Novembro 7). Global Terrorism Database. Universidade de Maryland, Consórcio Nacional para o Estudo do Terrorismo e Respostas ao Terrorismo. Disponível em: https://www.start.umd.edu/gtd/

Hoffman, B. (1998). Inside terrorism. New York: Columbia University Press.

Hourani, A. (2013). Uma história dos povos árabes. São Paulo: Companhia de bolso.

Laville, C. \& Dionne, J. (1999). A construção do saber: manual de metodologia da pesquisa em ciências humanas. Porto Alegre: Artes Médicas Sul; Belo Horizonte: EDUFMG.

Lepp, A. \& Gibson, H. (2008). Sensation seeking and tourism: Tourist role, perception of risk and destination choice. Tourism Mangament, 29(4), 740-750. https://doi.org/10.1016/j.tourman.2007.08.002

Lipovetsky, G. \& Serroy, J. (2015). A estetização do mundo: viver na era do capitalismo artista. São Paulo: Companhia das Letras.

Liu, X., Li, J. J. \& Yang, Y. (2015). Travel arrangement as a moderator in image - satisfaction - behavior relations: An investigation of Chinese outbound travelers. Journal of Vacation Marketing, 21(3), 225-236. https://doi.org/10.1177/1356766714567797

Liu, A. \& Pratt, S. (2017). Tourism's vulnerability and resilience to terrorism. Tourism Management, 60, 404 417.https://doi.org/10.1016/i.tourman.2017.01.001

Kiliçlar, A., Usakli, A. \& Tayfun, A. (2017). Terrorism prevention in tourism destinations: Security forces vs. civil authority perspectives. Journal of Destination Marketing \& Management, In press.

Marion, K., Reintinger, C. \& Schmude, J. (2015). Reject or select: Mapping destination choice. Annals of Tourism Research, 54, 48-64. https://doi.org/10.1016/j.annals.2015.06.003

Molina, A., Gómez, M. \& Consuegra, D. M. (2010). Tourism marketing information and destination image management. African Journal of Business Management, 4(5), 722-728.

Moraga, E. T., Artigas, E. A. M. \& Irigoyen, C. C. (2012). Desarrollo y propuesta de una escala para medir la Imagen de los Destinos Turísticos (IMATUR). Revista Brasileira de Gestão de Negócios, 14(45), 400-418. https://doi.org/10.7819/rbgn.v14i45.1349

Nevalsky, R. C. (2015). Developing terrorism coverage: Variance in news framing of the january 2015 in Paris and Borno. Critical Studies on Terrorism, 8(3), 466-477. https://doi.org/10.1080/17539153.2015.1096656

Nitsch, V. \& Schumacher, D. (2004). Terrorism and international trade: An empirical investigation. European Journal of Political Economy, 20, 423-433. https://doi.org/10.1016/i.ejpoleco.2003.12.009

Nye Jr., J. (2005). Understanding international conflicts: An introduction to theory and history. 5 ed. New York: Pearson Education.

Origem da Palavra. (2017, Novembro, 7). Consultório Etimológico. Disponível em: http://origemdapalavra.com.br/site/pergunta/terrorismo/ 2011

Oz, Amós. (2004). Como curar um fanático: Israel e Palestina: entre o certo e o certo. São Paulo: Companhia das Letras.

Paraskevas, A. (2013). Aligning strategy to threat: A baseline anti-terrorism strategy for hotels. International Journal of Contemporary Hospitality Management, 25(1), 140-162. https://doi.org/10.1108/09596111311290264

Parra, E. G. (2015). Terrorismo y Turismo. Facultat de Ciéncies Juridiques i Económiques, Universitat Jaume I. Castellón, Espanha. 
Petkova, E. P., Martinez, S., Schlegelmilch, J. \& Redlener, I. (2017). Schools and terrorism: Global trends, impacts, and lessons for resilience. Studies in Conflict \& Terrorism, 40(8), 701-711. https://doi.org/10.1080/1057610X.2016.1223979

Piazza, J. A. (2013). The cost of living and terror: Does consumer price volatility fuel terrorism? Southern Economic Journal, 79(4), 812-831. https://doi.org/10.4284/0038-4038-2012.270

Pine, J. \& Gilmore, J. (1998). The Experience Economy. Harvard Business Review, 76(4), 97-105.

Pizam, A. \& Fleischer, A. (2002). Severity versus frequency of acts of terrorism: Which has a larger impact on tourism demand? Journal of Travel Research, 40(3), 339. https://doi.org/10.1177/0047287502040003011

Prayag, G. (2008). Image, satisfaction and loyalty: The case of Cape Town. Journal of Tourism and Hospitality Research, 19(2), 205-224. https://doi.org/10.1080/13032917.2008.9687069

Ritchie, B. W. (2004). Chaos, crises and disasters: A strategic approach to crisis management in the tourism industry. Tourism Management, 25, 669-683. https://doi.org/10.1016/i.tourman.2003.09.004

Saha, S. \& Yap, G. (2014). The Moderation Effects of Political Instability and Terrorism on Tourism Development: A Cross-Country Panel Analysis. Journal of Travel Research, 53(4). https://doi.org/10.1177/0047287513496472

Said, E. W. (1990). Orientalismo: o oriente como invenção do ocidente. São Paulo: Companhia das Letras.

Saint-Pierre, H. L. (2015). 11 de setembro: do terror à injustificada arbitrariedade e o terrorismo do estado. Revista de Sociologia e Política, 23(53), 9-26. https://doi.org/10.1590/1678-987315235302

Samitas, A., Asteriou, D., Polyzos, S. \& Kenourgios, D. (2018). Terrorist incidents and tourism demand: Evidence from Greece. Tourism Management Perspectives, 25, 23-28. https://doi.org/10.1016/j.tmp.2017.10.005

Sampieri, R. H., Collado, C. F. \& Lucio, P. B. (2006). Metodologia da pesquisa. 3a ed. São Paulo: McGraw-Hill. Sandler, T. (2015). Terrorism and counterterrorism: An overview. Oxford Economic Papers, 67(1), 1-20. https://doi.org/10.1093/oep/gpu039

Seraphin, H. (2017). Terrorism and tourism in France: the limitations of dark tourism. Worldwide Hospitality and Tourism Themes, 9(2), 187-195. https://doi.org/10.1108/WHATT-09-2016-0044

Stafford, G. \& Yu, L. \& Armoo, A. K. (2002). Crisis Management and Recovery: How Washinton, D.C., Hotels Responded to Terrorism. Cornell Hotel and Restaurant Administration Quarterly. 27-40. https://doi.org/10.1177/0010880402435003

Shaw, R. Terrorism. In: J. Jafari. Encyclopedia of Tourism. Londres: Routledge, 2000.

Silke, Andrew (2003). Terrorists, victims and society: Psychological perspectives on terrorism and its consequences. New Jersey: Wiley. https://doi.org/10.1002/9780470713600

Simková, E. \& Holzner, J. (2014). Motivation of Tourism Participants. Procedia - Social and Behavioural Sciences, 660-664. https://doi.org/10.1016/j.sbspro.2014.12.455

Schmöll, G. A. (1977). Tourism promotion: marketing background, promotion techniques and promotion planning methods. Tourism International Press.

Son, A. (2005). The measurement of tourist destination image: applying a sketch map technique. International Journal of Tourism Research, 7(4-5), 279-294. https://doi.org/10.1002/jtr.532

Sonmez, S., Y. Apostolopoulos. (1999). Tourism in crisis: Managing the effects of terrorism. Journal of Travel Research, 38(1), 13-18. https://doi.org/10.1177/004728759903800104

Tarlow, P. E. (2006). A social theory of terrorism and tourism. In Y. Mansfeld \& A. Pizam (eds.) Tourism, security and safety: From theory to practice. Amsterdam: Elsevier. https://doi.org/10.1016/B978-0-7506-78988.50006-0

Wainberg, J. (2005). Comunicação internacional e intercultural: A luta pelo imaginário social, o temor à segregação e o caso do terrorismo. Civitas - Revista de Ciências Sociais, 5 (2), 275-295.

Walters, G., Wallin, A. \& Hartley, N. (2018). The threat of terrorism and tourist choice behavior. Journal of Travel Research, In press. https://doi.org/10.1177/0047287518755503

Wright, L. (2007). O vulto das torres: a Al-Qaeda e o caminho até o 11/09. São Paulo: Companhia das Letras.

Woo, G. (2015). Understanding the principles of terrorism risk modeling from Charlie Hebdo attack in Paris. Defence Against Terrorism Review, 7(1), 33-46. 


\section{Informações dos autores}

\section{Marcela Lidianny do Amaral Ferreira}

É mestranda em Hotelaria e Turismo pela Universidade Federal de Pernambuco. Tem graduação em Turismo pela Universidade Federal de Pernambuco.

Suas contribuições no artigo estão nas seguintes atividades: definição do tema, desenvolvimento do esboço inicial da proposta da pesquisa, realização da coleta de dados, análise dos dados, elaboração da conclusão do estudo.

E-mail: marcela.turismope@hotmail.com

ORCID: https://orcid.org/0000-0002-8308-0856

\section{Pollyanna Fraga Graciano}

Mestranda em Hotelaria e Turismo pela Universidade Federal de Pernambuco. Tem graduação em Turismo pela Universidade Federal de Pernambuco.

Suas contribuições no artigo estão nas seguintes atividades: definição do tema, desenvolvimento do esboço inicial da proposta da pesquisa, realização da coleta de dados, análise dos dados e elaboração da conclusão do estudo.

E-mail: lyafraga@gmail.com

ORCID: https://orcid.org/0000-0002-6736-7961

\section{Sérgio Rodrigues Leal}

Tem doutorado em turismo pela Universidade de Surrey, no Reino Unido, Mestrado em Turismo pela Universidade James Cook, na Austrália, e Bacharelado em Turismo com MBA em Marketing de Serviços pela Universidade Federal de Pernambuco (UFPE). É Professor Adjunto do Departamento de Hotelaria e Turismo e Vice-Coordenador do Programa de Pós-Graduação em Hotelaria e Turismo da UFPE, Diretor da Academia Internacional para o Desenvolvimento da Pesquisa em Turismo no Brasil (ABRATUR) e Diretor Acadêmico da Associação Nacional de Pesquisa e Pós-Graduação em Turismo (ANPTUR).

Suas contribuições para o trabalho incluem, mas não se limitam a, escolha do tema, criação da equipe de pesquisa, definição da metodologia empregada, revisão de versões preliminares do artigo e sua tradução para inglês.

E-mail: sergio.rleal@ufpe.br

ORCID: https://orcid.org/0000-0002-4898-4489

\section{Marconi Freitas da Costa}

É Doutor em Administração pela FEA/USP. Professor Permanente do Programa de Pós-Graduação em Hotelaria e Turismo - PPHTur/UFPE. Foi bolsista Fulbright para o estágio doutoral nos EUA, durante esse período foi Visiting Scholar na Questrom School of Business, Boston University e Audit Student na Sloan School of Management, Massachusetts Institute of Technology - MIT.

Suas contribuições no artigo estão nas seguintes atividades: contribuição na reestruturação do esboço inicial da pesquisa, atualização da revisão da literatura, realização da análise dos dados, revisão da conclusão do estudo e tradução para o inglês.

E-mail: marconi costa@hotmail.com

ORCID: https://orcid.org/0000-0001-9888-8359 